\title{
Penerapan Metode Demonstrasi Dalam Meningkatkan Kemampuan Siswa Menunjukkan Nilai-Nilai Musik Non Tradisional
}

\author{
PRAPTIN YUNELZY \\ Dinas Pendidikan Kabupaten Kampar \\ SMP Negeri 4 Siak Hulu \\ E-mail : praptinyunelzy@gmail.com
}

\begin{abstract}
Learning music becomes a learning that not everyone can get their knowledge, for students at the junior high school level this learning becomes the burden of the teacher in conveying their knowledge. Not all students can successfully learn it and with the demonstration learning method shown by the teacher will motivate students to study harder. Through classroom action research conducted and analyzed qualitatively, information was obtained that the application of demonstration methods was able to improve students' ability to demonstrate the values of non-traditional music and build their motivation to learn.
\end{abstract}

Keywords: Demonstation Method; Student Ability; Value of Non-Traditional Music

Kegiatan pembelajaran dirancang mengikuti prinsip-prinsip belajarmengajar, baik terkait dengan keluasan bahan/materi, pengalaman belajar, tempat dan waktu belajar, alat/sumber belajar, bentuk pengorganisasian kelas dan cara penilaian. Dalam kegiatan pembelajaran guru perlu memberikan dorongan kepada peserta didik untuk mengungkapkan kemampuannya dalam membangun gagasan. Guru berperan sebagai fasilitator dan bertangung jawab untuk menciptakan situasi yang dapat menumbuhkan prakarsa, motivasi, dan tanggung jawab peserta didik untuk belajar. Di samping itu guru dalam mengelola kegiatan pembelajaran hendaknya mampu mengembangkan pola interaksi antara berbagai pihak yang terlibat di dalam pembelajaran dan harus pandai memotivasi peserta didik untuk terbuka, kreatif, responsif, interaktif dalam kegiatan pembelajaran.

Kualitas pembelajaran dapat diukur dan ditentukan oleh sejauh mana kegiatan pembelajaran tertentu dapat menjadi alat perubahan tingkahlaku peserta didik ke arah yang sesuai dengan tujuan/kompetensi yang telah ditetapkan. Oleh karena, itu, guru dituntut mampu merancang dan melaksanakan kegiatan pembelajaran yang sesuai dengan karakteristik perkembangan dan kebutuhan anak didik, keadaan sekitar, dan ketersediaan sarana dan prasarana pendidikan.

Dengan demikian, dapat disimpulkan bahwa media adalah bagian yang tidak terpisahkan dari proses belajar mengajar demi demi tercapainya tujuan pendidikan pada Umumnya dan tujuan pembelajaran di sekolah pada khususnya. Begitu juga penggunaan media pembelajaran yang diterapkan pada Sekolah Menegah Atas, dimana diharapkan dengan diberikannya alat pembelajaran maka siswa akan mudah memahami dan mengerti tentang berbegai pelajaran yang disampaikan.

Permasalahan yang dihadapi dalam belajar karya seni khususnya seni musik antara lain yang dialami siswa kelas VIII pada SMP N 4 Siak Hulu, dimana mereka kurang memahami dan kurang mampu untuk mengaktualisasikan konsep musik itu sendiri, karena selama ini mereka mendapatkan materi ini dengan menggunakan metode ceramah. Pada kesempatan ini akan dicoba penerapan simulasi computer dalam rangka meningkatkan pemahaman siswa akan karya seni musik.

Berdasarkan gejala yang diobservasi tersebut di atas maka penulis tertarik melakukan penelitian tindakan kelas dalam rangka meningkatkan 
kemampuan logika pemahaman karya seni musik melalui penggunaan alat edukatif dalam sebuah judul: Mengekspresikan Diri Melalui Karya Seni Music Melalui Metode Simulasi Komputer Pada Siswa Kelas Viii Di Smp N 4 Siak Hulu.

Pelaksanaan proses pembelajaran sama dengan pelaksanaan proses belajar menagajar. Suryosubroto (2002) mengemukakakn bahwa pelaksanaan proses belajar mengajar adalah proses berlangsungnya belajar mengajar di kelas yang merupakan inti dari kegiatan pendidikan di sekolah. Winarno Surachmad (1983) menambahkan bahwa pelaksanaan pengajaran adalah interaksi guru dengan murid dalam rangka penyampaian bahwa pelajaran keapda siswa dan untuk mencapai tujuan pengajaran. Berdasarkan kajian pustaka dapat disimpulkan bahwa pelaksanaan pembelajaran adalah sebagai terjadinya interaksi guru dengan siswa dalam rangka menyampaikan bahan pelajaran kepada siswa untuk mencapai tujuan.

Proses pembejalaran yang dilaksanakan oleh guru diutamakan mengacu pada kemampuan yang akan dicapai dan mengoptimalkan pemberian pengajaran yang kreatif pada anak didik dengan menggunakan Alat Permainan Edukatif (APE). Moh. Uzer Usman (2001) menyatakan bahwa pembelajaran merupakan suatu proses yang mengandung serangkaian perbuatan guru dan siswa atas dasar hubungan timbal balik yang berlangsung dalam situasi edukatif untuk mencapai tujuan tertentu. Interaksi atau hubungan timbal balik antara guru dan siswa itu merupakan syarat utama bagi berlangsungnya proses belajar mengajar. Dalam hal ini bukan hanya menyampaikan pesan berupa materi pembelajaran melainkan penanaman sikap dan nilai pada diri siswa yang sedang belajar.

Alat sama dengan media kata media berasal dari bahasa Latin medius yang secara harfiah berarti 'tengah', 'perantara' atau 'pengantar'. Dalam bahasa Arab, media adalah perantara attau pengantar pesan dari pengirim kepada penerima pesan. Gerlach \& Ely dalam Arsyad (2005) menyatakan bahwa media apabila dipahami secara garis besar adalah manusia, mnateri, atau kejadian yang membangun kondisi yang membuat siswa mampu memperoleh pengetahuan, keterampilan, atau sikap. Dalam pengertian ini, guru, buku teks, dan lingkungan sekolah merupakan media. bicara lebih khusus. pengertian media dalam proses belajar mengajar cenderung diartikan sebagai alat-alat grafis, photografis, atau elektronis untuk menangkap, memproses, dan menyusun kembali informasi visual atau verbal.

Pemerolehan pengetahuan dan keterampilan, perubahan-perubahan sikap dan perilaku dapat terjadi karena interaksi antara pengalaman baru dengan pengalaman yang pernah dialami sebelumnya. Bruner (1966) ada tiga tingkatan utama modus belajar, yaitu jwngalaman langsung (enaetive), pengalaman piktorial/gambar (iconic), dan pengalaman abstrak (symbolic). Pengalaman langsung adalah mengerjakan, misalnya arti kata 'simpul' dipahami dengan langsung membuat simpul. Pada tingkatan kedua yang diberi label iconic

Artinya gambar, kata 'simpul' dipelajari dari gambar, lukisan, foto, atau film. Selanjutnya, pada tingkatan simbol, siswa membaca (atau mendengar) kata 'simpul' dan mencoba mencocokl:annya dengan 'simpul' pada image mental atau mencocokkannya dengan pengalamanma membuat 'simpul'. Ketiga tingkat pengalaman ini saling berinteraksi dalam upaya memperoleh 'pengalaman' (pengetahuan. keterampilan. atau sikap) yang baru.

Levie \& Lentz (1982) mengemukakan empat fungsi media pembelajaran, khususnya media visual, yaitu (a) fungsi atensi, (b) fungsi afektif, (c) fungsi kognitif, dan (d) fungsi kompensatoris. Fungsi atensi media visual merupakan inti, yaitu menarik dan mengarahkan perhatian siswa untuk 
berkonsentrasi kepada isi pelajaran yang berkaitan dengan makna visual yang ditampilkan atau menyertai teks materi pelajaran. Seringkali pada awal pelajaran siswa tidak tertarik dengan materi pelajaran atau mata pelajaran itu merupakan salah satu pelajaran yang tidak disenangi mereka sehingga mereka tidak memperhatikan. Melalui gambar, khususnya gambar yang diproyeksikan melalui overhead projector dapat mengarahkan perhatian mereka kepada pelajaran yang akan mereka terima. Dengan demikian kemungkinan untuk memperoleh dan mengingat isi pelajaran semakin besar.

Fungsi afektif media visual dapat terliht dari tingkat kenikmatan siswa ketika belajar (atau membaca) teks gambar. Gambar atau lambang visual dapat mengugah emosi dan sikap siswa, misalnya informasi menyangkut masalah emosi.

Fungsi kognitif media visual terlihat dari temuan-temuan penelitian yang mengungkapkan bahwa lambang atau gambar memperlancar pencapaian tujuan untuk memahami dan mengingat informasi atau pesan yang terkandung dalam gambar. Fungsi kompensatoris media pembelajaran terlihat dari penelitian bahwa media visual yang memberikan konteks untuk memahami teks membantu siswa yang lemah dalam membaca untuk mengorganisasikan informasi dalam teks dan mengingatnya kembali. Dengan kata lain media pembelajaran berfungsi untuk mengakomodasikan siswa yang lemah dan lambat menerima dan mendefenisikan isi pelajaran yang disajikan dengan teks atau disajikan secara verbal.

Arsyad (2002) menjelaskan bahwa media berbasis visual (image atau perumpamaan) memegang peran yang amat penting dalam proses belajar. Media visual dapat memperlancar pemahaman dan memperkuat ingatan. Bentuk media visual bisa berupa gambar, diagram, peta dan grafik.

Berdasarkan penjelasan di atas, jelas dapat diketahui bahwa dalam proses pembelajaran dengan menggunakan alat pembelajaran edukatif digunakan media visual, dimana dalam tulisan ini berupa simulasi komputer pada mata pelajaran seni budaya.

\section{METODE}

Metode yang digunakan dalam penelitian ini adalah metode penelitian tindakan kelas merupakan: (1) penelitian partisipatoris yang menekankan pada tindakan dan refleksi berdasarkan pertimbangan rasional dan logis untuk melakukan perbaikan terhadap suatu kondisi nyata; (2) memperdalam pemahaman terhadap tindakan yang dilakukan dan (3) memperbaiki situasi dan kondisi kelas pembelajaran secara praktis". (Depdiknas, 2006). Secara singkat, PTK bertujuan untuk mencari pemecahan permasalahan nyata yang terjadi di kelas, sekaligus mencari jawaban ilmiah bagaimana masalah-masalah tersebut bisa dipecahkan melalui suatu tindakan perbaikan.

Pendekatan yang digunakan dalam penelitian tindakan ini ialah pendekatan kualitatif. Artinya, penelitian ini dilakukan karena ditemukan permasalahan masih kurangnya penggunaan alat edukatif dari mata pelajaran seni budaya. Permasalahan ini ditindaklanjuti dengan cara menerapkan alat edukatif simulasi komputer yang dilakukan oleh guru kelas. Kegiatan tersebut diamati kemudian dianalisis dan direfleksi. Hasil revisi kemudian diterapkan kembali pada siklussiklus berikutnya.

Kegiatan penelitian tindakan kelas ini terdiri atas beberapa tahap yaitu:
1. Perencanaan
2. Pelaksanaan
3. Pengamatan
4. Refleksi

Tindakan yang dilakukan dalam penelitian ini adalah menerapakan alat edukatif simulasin komputer kepada siswa dalam rangka meningkatkan hasil belajar karya seni musik kelas VIII mata pelajaran Seni budaya SMP N 4 Siak Hulu. Karena keterbatasan waktu, penelitian 
tindakan kelas ini hanya dilaksanakan sebanyak 3 siklus masing-masing siklus dilaksanakan selama 3 minggu.

Analisa data yang digunakan dalam penelitian ini adalah analisa data kualitatif yang bersumber dari data primer maupun empiris. Melalui analisa data ini, dapat diketahui baik atau tidaknya hasil belajar siswa pada mata pelajaran seni budaya melalui penerapan alat edukasi simulasi komputer yang merupakan fokus dari penelitian tindakan kelas ini.

\section{HASIL}

Penelitian tindakan kelas (PTK) ini dilaksanakan dalam dua siklus. Hal ini dikarenakan keterbatasan waktu yang tersedia, serta dengan dua siklus sudah penulis anggap cukup untuk peningkatan hasil belajar karya seni musik siswa pada mata pelajaran seni budaya di kelas.

Dari hasil rekapitulasi data tersebut dapat diketahui pada siklus pertama hasil belajar siswa pada mata pelajaran seni budaya melalui penerapan alat edukatif simulasi komputer di kelas VIII dinyatakan tuntas sebanyak 63,3\%. Hal ini dikarenakan banyak siswa yang masih kurang mengerti penggunaan alat edukasi simulasi komputer tersebut pada saat dijelaskan oleh guru didepan.

Setelah selesai satu siklus maka diadakan refleksi mengenai kelemahan atau kekurangan dari pelaksanaan tindakan pada siklus pertama. Refleksi dilaksanakan bersama-sama berkolaborator untuk menentukan tindakan perbaikan pada siklus berikutnya. Dari hasil refleksi dapat diambil suatu kesimpulan bahwa perlu didampingi setiap siswa pada saat penggunaan alat edukatif simulasi komputer dengan cara satu siswa satu guru pendamping. Teknisnya dengan setiap siswa antri berdasarkan absen untuk melakukan simulasi dengan bimbingan guru.

Dari hasil rekapitulasi data tersebut dapat diketahui pada siklus kedua hasil pekerjaan rumah siswa mata pelajaran seni budaya dinyatakan baik, yang mencapai $60 \%$ bahwa adanya perubahan dari siklus kedua dan perlu dilanjutkan ke siklus ke 3 .

Setelah selesai pelaksanaan tindakan pada siklus kedua maka diadakan refleksi mengenai kelemahan atau kekurangan dari pelaksanaan tindakan pada siklus kedua tersebut. Refleksi dilaksanakan bersamasama berkolaborator untuk menentukan tindakan perbaikan pada siklus berikutnya. Dari hasil observasi dan data yang diperoleh, peneliti mengambil kesimpulan bahwa tindakan yang dilaksanakan pada siklus kedua dinyatakan lebih baik bila dibandingkan dengan siklus pertama dan penulis nyatakan cukup sampai di siklus 2 dikarenakan keterbatasan waktu dan sudah ada peningkatan yang signifikan dari pada siklus 1.

Dari hasil rekapitulasi data tersebut dapat diketahui pada siklus kedua hasil pekerjaan rumah siswa mata pelajaran seni budaya dinyatakan baik, yang mencapai $70 \%$ dan dapat disimpulkan bahwa adanya perubahan dari siklus kedua.

Setelah selesai pelaksanaan tindakan pada siklus kedua maka diadakan refleksi mengenai kelemahan atau kekurangan dari pelaksanaan tindakan pada siklus kedua tersebut. Refleksi dilaksanakan bersamasama berkolaborator untuk menentukan tindakan perbaikan pada siklus berikutnya. Dari hasil observasi dan data yang diperoleh, peneliti mengambil kesimpulan bahwa tindakan yang dilaksanakan pada siklus kedua dinyatakan lebih baik bila dibandingkan dengan siklus pertama dan penulis nyatakan cukup sampai di siklus 3 dikarenakan keterbatasan waktu dan sudah ada peningkatan yang signifikan dari pada siklus 1.

Grafik peningkatan hasil belajar karya seni musik siswa pada mata pelajaran seni budaya di kelas VIII dengan penerapan alat edukatif simulasi komputer dilihat dari. Untuk lebih jelasnya dapat dilihat pada grafik berikut ini: 


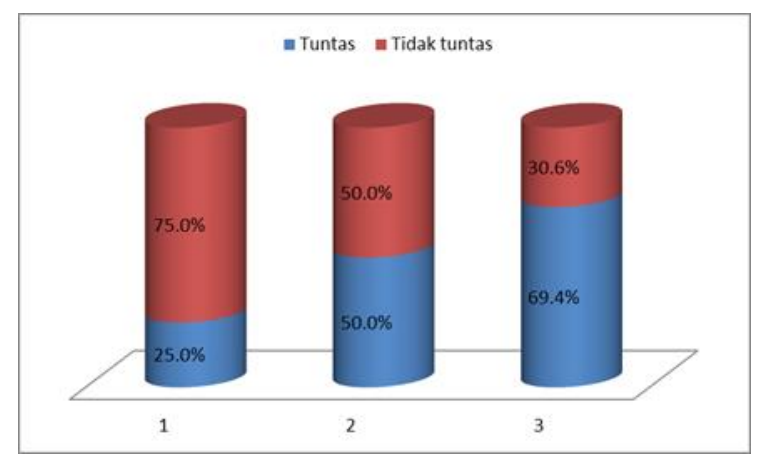

\section{PEMBAHASAN}

Berdasarkan analisis data, dari penelitian ini dapat ditarik kesimpulan bahwa, penerapan alat belajar edukatif simulasi komputer dalam rangka meningkatkan hasil belajar karya seni musik siswa di kelas VIII pada mata pelajaran seni budaya ternyata hasil belajar siswa meningkat. Dari awalnya hanya $63 \%$ siswa yang memiliki hasil belajar yang baik meningkat menjadi $60 \%$ dan siklus ke tiga menjadi $70 \%$ siswa yang memiliki hasil belajar yang baik.

Data yang diperoleh menunjukkan bahwa setelah dilakukan penerapan alat edukatif simulasi komputer, maka terbukti adanya pengaruh yang ke arah yang positif dalam meningkatkan hasil belajar karya seni musik siswa pada mata pelajaran seni budaya, penekanan ini dilakukan dengan melakukan pendampingan kepada siswa pada saat melakukan simulasi yaitu dengan satu siswa satu pendamping.

Melalui penerapan metode demonstrasi ini mampu merubah kemampuan siswa dan ini sesuai dengan pendapat Suroto dkk (2017) bahwa penerapan metode pembelajaran membuat hasil belajar semakin baik.

\section{SIMPULAN}

Melalui penelitian tindakan kelas yang dilakukan dan dianalisis secara kualitatif diperoleh informasi bahwa penerapan metode demonstrasi mampu meningkatkan kemampuan siswa dalam menunjukkan nilai-nilai musik non tradisional dan membangun motivasinya untuk belajar.

Diklat Review: Jurnal Manajemen Pendidikan dan Pelatihan

\section{DAFTAR RUJUKAN}

Achsin, A. 1986. Media Pendidikan dalam Kegiatan Belajar Mengajar. Ujung pandang: IKIP Ujung Pandang Press

Arsyad, Azhar. 2002. Media Pembelajaran. Jakarta: PT. Raja Grafindo Persada

Bruner, J. S. 1966. Toward a Theory of Instruction. Harvad University. Cambridge

Departemen Pendidikan Nasional Direktorat Jenderal Manajemen Pendidikan dasar dan Menengah, 2006, Pedoman Pembelajaran di taman kanak-kanak. Penerbit Depdikbud, Jakarta.

Moh. Uzer Usman. 2005. Menjadi Guru Profesional. Bandung : Remaja Rosdakarya.

Surakhmad, Winarno. 1982. Pengantar Penelitian Ilmiah, Dasar, Metode, Teknik. Bandung: Transito

Suryosubroto. 2002. Proses Belajar Mengajar Di Sekolah. Jakarta: Rineka Cipta

Nasution, 1996, Metode Penelitian Naturalistik Kualitatif, Penerbit Tarsito, Bandung.

Patmonedowo, Soemiartri. 1995, Pendidikan Anak Prasekolah. Penerbit Rineka, Jakarta.

Purwanto, Ngalim, 1990, Psikologi Pendidikan. Penerbit Remaja Rosdakarya, Bandung.

Suroto, B., Novita, N., Pailis, E. A., Waldelmi, I., \& Fatkhurahman, F. (2017). Metode Penelitian Tindakan Solusi Bagi Masalah Sosial. Jurnal Diklat Review, 1(1), 25-28. 